\title{
GCU
}

Glasgow Caledonian

University

University for the Common Good

\section{Risk-based framework accounting for the effects of vegetation in geotechnical engineering}

Mickovski, B. Slobodan

Published in:

ce/papers

DOI:

10.1002/cepa.700

Publication date:

2018

Document Version

Author accepted manuscript

Link to publication in ResearchOnline

Citation for published version (Harvard):

Mickovski, BS 2018, 'Risk-based framework accounting for the effects of vegetation in geotechnical engineering', ce/papers, vol. 2, no. 2-3, pp. 377-382. https://doi.org/10.1002/cepa.700

\section{General rights}

Copyright and moral rights for the publications made accessible in the public portal are retained by the authors and/or other copyright owners and it is a condition of accessing publications that users recognise and abide by the legal requirements associated with these rights.

Take down policy

If you believe that this document breaches copyright please view our takedown policy at https://edshare.gcu.ac.uk/id/eprint/5179 for details of how to contact us. 


\title{
Risk-based framework accounting for the effects of vegetation in geotechnical engineering
}

\author{
MICKOVSKI B. Slobodan ${ }^{1}$ \\ ${ }^{1}$ Ph.D., M.Sc., B.Sc.; CEng MICE, CSci MCIWEM, FHEA, School of Engineering and Built Environment, \\ Glasgow Caledonian University, Cowcaddens Rd, Glasgow, Scotland; Slobodan.Mickovski@gcu.ac.uk
}

\begin{abstract}
Eco-engineering techniques comprise the use of vegetation, either alone or in combination with traditional civil engineering structures, for control of soil erosion and shallow landslides. The main perceived disadvantage in the design of these solutions is often listed as the uncertainty, and thus, hazards and risks related to the living material. In order to account and mitigate for these uncertainties, an approach is proposed where a number of novel methods aimed at enhancement of the understanding of the mechanisms of soil-root reinforcement are presented. These methods range from fundamental assessment of suction stress induced by the vegetation in the design phase, through assessment of root growth on slopes during construction and operation, to the assessment of long-term slope stability and sustainability of the solution implemented. The results of this study show that multidisciplinary knowledge of the risks and processes occurring at different project stages as well as input from relevant disciplines are needed in order to inform the geotechnical design and construction.
\end{abstract}

Keywords: Root reinforcement, suction stress, slope stability, risk assessment, eco-engineering

\section{INTRODUCTION}

Risk can be defined as a product of the hazard, the exposure and the vulnerability of the elements at risk. The exposure refers to the inventory of elements in an area in which hazard events may occur (Cardona et al., 2012) such as infrastructure, resources or population. However, the exposure is not sufficient determinant of risk because it is possible to be exposed but not vulnerable. Vulnerability, on the other hand, can be caused by the lack of resilience and capacity to anticipate, cope with, and adapt to extremes and change. The vulnerability of exposed elements plays an increasingly important role in the risk assessment of less extreme events (higher probability, lower intensity) such as erosion and shallow landslides. The cumulative effects of small- or medium-scale, recurrent instability events at the local scale (site, section etc.) can significantly affect the social options and resources as well as the capacity of societies and communities to prepare for and respond to similar events in the future. High vulnerability and exposure are generally the outcome of skewed development processes, such as those associated with environmental mismanagement, demographic changes, rapid and unplanned urbanization in hazardous areas (Cardona et al 2012) - all of which resonate with major geotechnical projects such as transportation networks construction, building at or near natural or man-made slopes, etc.

Eco-engineering (or ground bio-engineering as a significant part of it) techniques are a part of environmental geotechnics and they comprise the use of vegetation, either alone or in combination with traditional civil engineering structures, for control of soil erosion and shallow landslides (Mickovski and Thomson, 2016). The specificity of these techniques is that in them the vegetation is employed to perform an engineering function (soil strengthening) but also to enhance the resilience capacity of the treated area due to the self-repairing characteristics of the vegetation used. Ecoengineering solutions can also provide a combination of sustainability benefits such as protection against soil erosion in the short-term, long-term stabilisation due to the reinforcement effect of the 
roots on the soil, short- and long-term provision of ecological bio-diversity and recreational value of the treated areas (Mickovski, 2016). The advantages of eco-engineering solutions over traditional civil engineering solutions include relatively low costs, ease of construction, and low landscape impact. The main disadvantage in the design of these solutions is often listed as the uncertainty, and thus, hazards and risks related to the living material, i.e. plants with their roots, such as their distribution underground as well as the mechanical and hydrological characteristics which tend to vary with the type and age of the plants used.

The vegetation has potential to reinforce the soil through the mechanical and hydrological effects of the roots. Increased soil strength would contribute towards reducing the risks of mass wasting on slopes in terms of erosion and shallow landslides. The investigations of the vegetation effects in the past have been usually restricted to either mechanical or hydrological and have usually been carried out at a micro, meso or macro scale. For full understanding of the effects of vegetation on slope stability and soil strength in general, a holistic, risk-based framework investigating the combined effects at different scales can be incorporated into a geotechnical risk assessment framework with minor modifications and clarifications. The aim of this study is to outline the major uncertainties and risks associated with the use of vegetation for soil reinforcement and to propose ways of mitigating against them. This would enable the inclusion of the vegetation-based elements into the more general geotechnical risk assessment framework.

\section{RISKS ASSOCIATED WITH VEGETATION EFFECTS ON SOIL STRENGTH}

To quantify the vegetation-based risks in a project combining traditional civil engineering materials and living materials (vegetation), a generic framework (Fig.1) is proposed based on adaptation of published literature (Mickovski, 2014) and the assumption that the instability events such as erosion and shallow landslides are triggered by the changing climate (e.g. changing rainfall pattern).

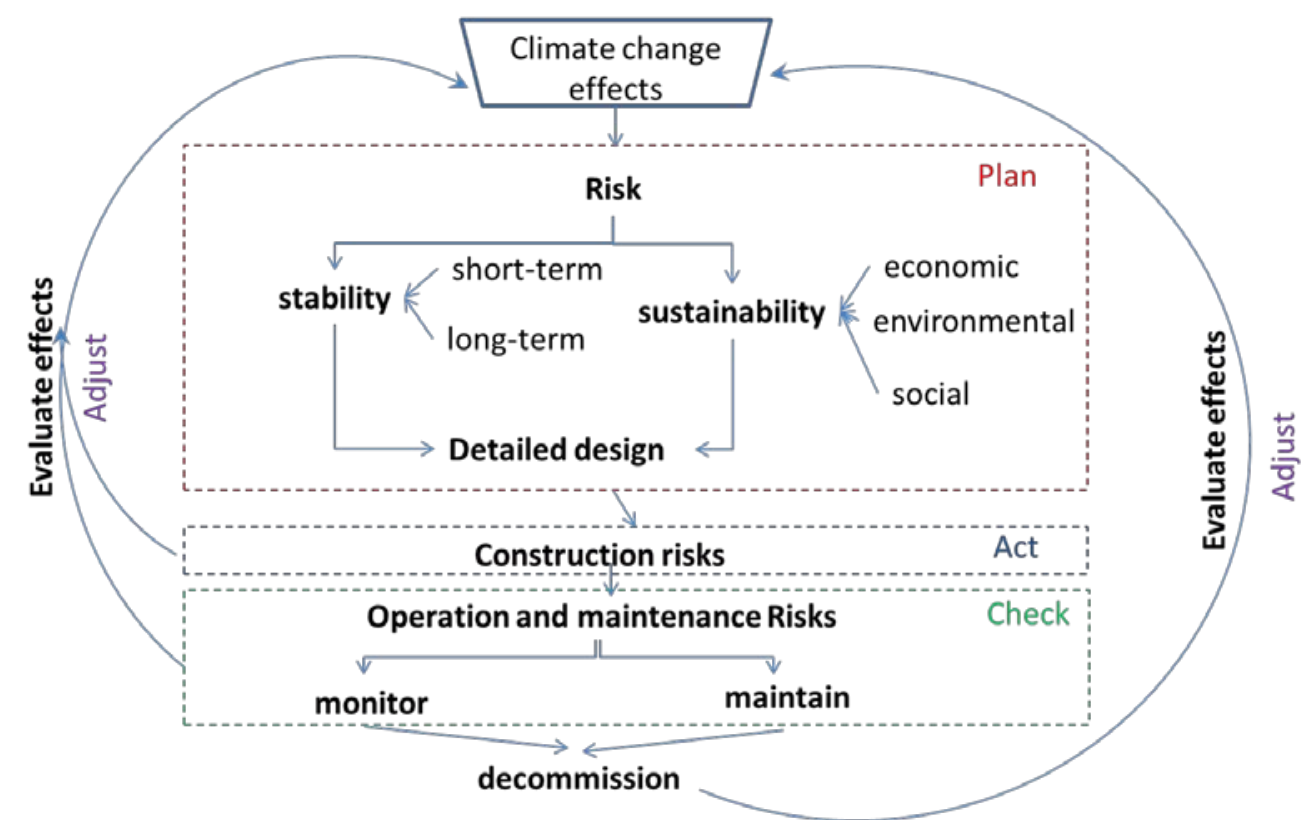

Figure 1. Proposed risk-based framework for analysis and integration of vegetation-related parameters in geotechnical design and construction

Assuming that the geotechnical elements of the project will be risk-assessed using adequate methods (e.g. van Staveren 2007; Santos et al. 2015), the vegetation elements will have to be risk-assessed for each project stage. In this respect, the major risks during the planning stage would be: awareness of 
the potential of vegetation to perform an engineering function, assignment of engineering function or mix of functions to the vegetation component (Coppin and Richards, 2007), and the motivation /drivers for inclusion of vegetation in the design. During the investigation stage, the risks associated with vegetation will include characterization and sampling frequency as well as the multidisciplinary approach towards the investigation. Within the design stage the risks associated with vegetation will include the determination of the mechanical and hydrological effects on soil reinforcement as a result of, mainly, physio-morphology and distribution. The construction stage risks will include planting/seeding, and protection risks, while in the operation/maintenance stage risks will encompass the detail and frequency of inspections, monitoring and mitigation of any running problems.

\section{RISKS ASSESSMENT AND MITIGATION}

Indicators, indices, and probabilistic metrics are important measures and techniques for vulnerability and risk analysis and they are used in different shapes and forms in all areas of geotechnical engineering. However, these quantitative approaches need to be complemented with qualitative approaches in attempt to capture the full complexity and the various intrinsic aspects of ecoengineering in all project stages. For example, a sustainability assessment method based on key performance indicators (KPI; Fig. 2) relevant to eco-engineering (Mickovski and Thomson, in press) can be used as a planning tool in order to foresee and mitigate the vegetation-associated risks in the planning stage of the project. The benefit of using this approach is that it can be applied to all project stages and monitor the overall project performance based on sustainability as a driver while accounting for the traditional risks such as stability and engineering performance.

\begin{tabular}{|c|c|c|c|}
\hline \multicolumn{2}{|c|}{$\begin{array}{l}\text { Existing sustainability } \\
\text { assessment tools (CEEQUAL, } \\
\text { LEED, BREAM, etc) }\end{array}$} & \multicolumn{2}{|c|}{$\begin{array}{l}\text { Consultation with industry (client, } \\
\text { designer, contractor), academia, and } \\
\text { authors experience }\end{array}$} \\
\hline \multicolumn{4}{|c|}{ Sustainability assessment method with KPI specific to ecoengineering } \\
\hline $\begin{array}{l}\text { Environmental } \\
\text { sustainability } \\
\text { Geology } \\
\text { Land use } \\
\text { Water } \\
\text { Air } \\
\text { Noise/Vibr. } \\
\text { Visual } \\
\text { Waste } \\
\text { Flora }\end{array}$ & $\begin{array}{l}\text { Economic } \\
\text { sustainability } \\
\text { Direct costs } \\
\text { Indirect costs } \\
\text { Revenue } \\
\text { Contract } \\
\text { Procurement } \\
\text { Training } \\
\text { Legislative } \\
\text { Control }\end{array}$ & $\begin{array}{l}\text { Social / cultural } \\
\text { sustainability } \\
\text { Cultural heritage } \\
\text { Public access } \\
\text { Planning } \\
\text { Devel. control } \\
\text { Stakeholder eng. } \\
\text { Community eng. } \\
\text { Public govern. } \\
\text { Relationship mgmt. }\end{array}$ & $\begin{array}{l}\text { Engineering } \\
\text { performance } \\
\text { Stability } \\
\text { Durability } \\
\text { Constructability } \\
\text { Quality } \\
\text { Resistance } \\
\text { Resilience } \\
\text { Materials } \\
\text { Temporary works }\end{array}$ \\
\hline $\begin{array}{l}\text { Fauna } \\
\text { Ecology } \\
\text { Materials } \\
\text { Health+Safety }\end{array}$ & & & \\
\hline
\end{tabular}

Figure 2. An example of sustainability-based planning tool to accompany the planning but also the rest of the project stages where eco-engineering component features together with geotechnical component. (Adapted from Mickovski and Thomson, in press).

The investigation and design risks can be assessed and mitigated by enhancing the standard ground investigations (Fig 3a) and implementation of the findings into the risk assessment framework (Fig 3b). As in all project stages, appropriate and timely risk communication will be critical for effective adaptation and ecoengineering risk management. 


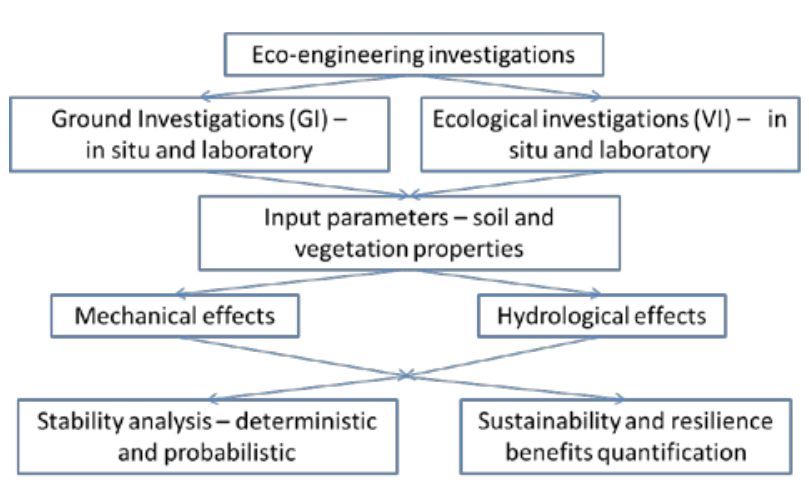

a)

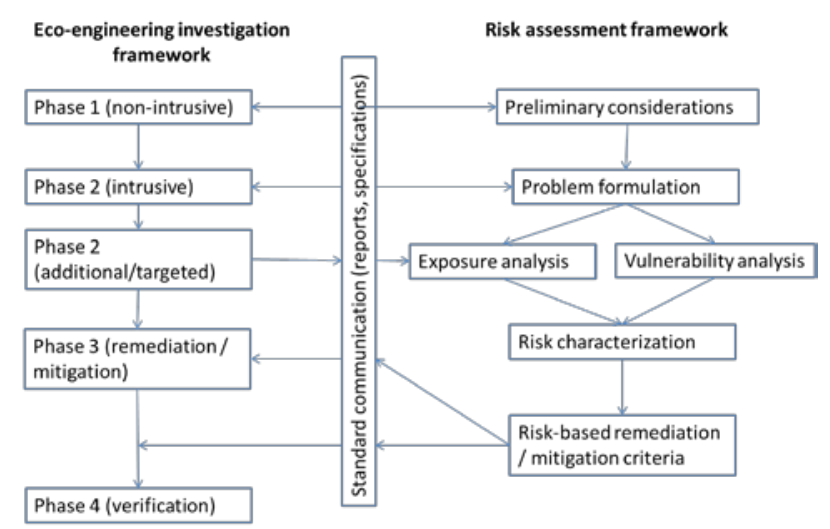

b)

Figure 3. a) Proposed eco-engineering investigations framework which includes for determination of the vegetation-related parameters to be used in analysis and design; b) Functional diagram for incorporation of the eco-engineering framework in the overall risk assessment framework.

The ground investigations can be enhanced with in situ and laboratory investigations for determination of root distribution, morphology, strength characteristics and variation in suction stress (Mickovski et al, 2017). The results of such investigations can then be used in the design of stabilisation or remediation measures through numerical modelling (Gonzalez-Ollauri and Mickovski, 2016, 2017a,b,c,d) or visualisation (Tardio et al, 2016). The major vegetation-related parameter that can be used in the traditional geotechnical design include the added cohesion of the root-soil composite which is a result of the root distribution and density but also the added soil suction which stems from the evapo-transpiration mechanisms of the vegetation (Gonzalez-Ollauri and Mickovski 2017d). This parameter is applicable, however, to vegetation with relatively fine roots (commensurate with the size of the soil particles) that tends to provide additional soil strength and ductility in the same way as steel reinforces concrete. For design with larger, structural roots (usually trees), the properties (e.g. geometry/taper/length, bending strength, shear strength, soil-root friction, modulus of elasticity) of representative roots need to be determined through targeted investigations. Once these are known, the effect of these roots can be modelled as a structural reinforcement of the soil (e.g. ground anchors, piles) using the standardised design procedures. To account for the natural variability in the material and physical properties, as well as the seasonal variability and distribution, a probabilistic analysis (e.g. Monte Carlo method; Gonzalez-Ollauri and Mickovski, 2017b,c) can be employed side by side with the similar approach that accounts for the variability in the soil properties.

The construction risks can be mitigated against by a combination of qualitative risk analysis and the use of best practice. The existing geotechnical construction risk mitigation strategies and best practices can be modified to include the vegetation component in terms of biological limitations, technical limitations, time limitations, and ecological limitations. For example, the most suitable time of the year for application of ecoengineering methods will be determined by the growth cycle of the plant material used which, in turn, is governed by seasonal factors (Schiechtl and Stern, 1996). Because of this, live building materials cannot be employed to replace the traditional engineering methods but only to supplement them. The biological risks can be mitigated by specification of live material appropriate to the climate (e.g. trees cannot be used in higher Alpine regions). The technical risks will be partly mitigated by extensive ecoengineering investigations as detailed above; however application of best practice during construction (e.g. Schiechtl and Stern, 1996) and appropriate method statements and quality plan will be required in order to close out any outstanding risk during construction.

Perhaps the biggest challenge in assessing and mitigating against the risks associated with vegetation lies in the operation/maintenance stages of a project. Considering the best practice at the moment, risk 
identification and assessment form part of the periodic regular inspection (McGregor and Mickovski, 2016) regime of the client or owner. However, the regular structural inspections should be enhanced with inspection of the vegetation element(s) and the interface between earthworks/structure and vegetation in light of the intended function of the vegetation. Effective monitoring (representative coverage, real-time, remotely sensed; Muvuna et al 2017) of the vegetation element and the soilstructure-environment interfaces will be of paramount importance. Monitoring programme should be informed by the planning and investigation outcomes as well as the geotechnical design report for the project. To mitigate against the risks of unforeseen extreme events (slope instability, flooding, invasive species, wind throw, plagues), emergency and mitigation measures will have to be planned in advance and comply with the basic maintenance and mitigation principles such as: minimal costs, minimal response time, ensuring full effectiveness of all technical, ecological, economic and esthetical objectives, safety of the site and adjacent structures/sites. Detailed records of any inspections and unforeseen events will be required to be kept as part of the quality management file for each project in order to be used as future reference or as part of a wider BIM application (Tawelian and Mickovski, 2016).

\section{DISCUSION AND CONCLUSIONS}

The preceding sections showed that the effect of vegetation on soil strength can be incorporated in the existing geotechnical risk assessment framework with modifications and enhancements that will account for the function, distribution and properties of vegetation. However, it becomes clear that multidisciplinary knowledge of the processes taking place at different scales, the associated risks, and input from relevant disciplines are needed in order to inform the geotechnical modelling and ecoengineering design. The challenge for the future remains the motivation of the geotechnical engineer to include ecoengineering design elements. Although the awareness of the effects of vegetation on soil strength and the various ecoengineering techniques and strategies where it can be applied has been consistently raised in the past few decades, there is still a reluctance to design with vegetation. One way to motivate the geotechnical engineers to use vegetation may be to include more formal training within the curriculum (Mickovski, 2017) where the use of vegetation in geotechnical design will be presented on the background of sustainability or risk. Another approach would be to include such training with in the continuous professional development of geotechnical engineers either under the auspices of the local/national geotechnical engineering associations and/or trans-national organisations such as the European Federation of Soil Water- and Bio-engineering (EFIB). The latter proved to be relatively successful within mainly the Alpine and the Mediterranean regions of Europe where ecoengineering originally was developed in Europe but there is work on promotion and motivation of these techniques to be done in other parts of Europe.

\section{ACKNOWLEDGEMENTS}

This study was partly funded by the Erasmus+ project ECOMED (575796-EPP-1-2016-1-ESEPPKA2-KA; www.ecomedbio.org)

\section{REFERENCES}

Cardona, O.D., M.K. van Aalst, J. Birkmann, M. Fordham, G. McGregor, R. Perez, R.S. Pulwarty, E.L.F. Schipper, and B.T. Sinh, 2012: Determinants of risk: exposure and vulnerability. In: Managing the Risks of Extreme Events and Disasters to Advance Climate Change Adaptation [Field, C.B., V. Barros, T.F. Stocker, D. Qin, D.J. Dokken, K.L. Ebi, M.D. Mastrandrea, K.J. Mach, G.-K. Plattner, S.K. Allen, M. Tignor, and 
P.M. Midgley (eds.)]. A Special Report of Working Groups I and II of the Intergovernmental Panel on Climate Change (IPCC). Cambridge University Press, Cambridge, UK, and New York, NY, USA, pp. 65108.

Coppin, N. J., Richards, I. G., 2007. Use of vegetation in civil engineering. CIRIA. London: Butterworths Construction Industry Research and Information Association. 2007.

Gonzalez-Ollauri, A. and Mickovski, S.B., 2017. Plant-Best: A novel plant selection tool for slope protection. Ecological Engineering 106 (2017): 154-173.

Gonzalez-Ollauri, A. and Mickovski, S.B., 2017. Hydrological effect of vegetation against rainfall-induced landslides. Journal of Hydrology, 549 : 374-387 .

Gonzalez-Ollauri, A. and Mickovski, S.B., 2017. Shallow landslides as drivers for slope ecosystems evolution and biophysical diversity. Landslides, 14(5): 1699-1714.

Gonzalez-Ollauri, A. and Mickovski, S.B., 2017. Plant-soil reinforcement response under different soil hydrological regimes. Geoderma, 285: 141-150.

González-Ollauri A., Mickovski S.B. 2016. Using the root spread information of pioneer plants to quantify their mitigation potential against shallow landslides and erosion intemperate humid climates. Ecological Engineering 95: 302-315.

McGregor, G. and Mickovski, S.B. 2016. A local authority’s risk-based approach to principal inspection frequency of structures. In: CETRA 2016, Proceedings 4th International Conference on Road and Rail Infrastructure. Lakusic, S. (ed.). University of Zagreb, p. 372-379

Mickovski, S.B. 2016. Why is the future ready for Environmental Geotechnics? Environmental Geotechnics 3: 63-64

Mickovski, S.B. 2017. Embedding technology to support the development of problem-solving skills in Geotechnical Design students. In: Proc 19th International Conference on Soil Mechanics and Geotechnical Engineering. W. Lee, J-S. Lee, H-K. Kim, D-S Kim (Eds). Seoul, Korea, September 17 - 22, 2017, pp 33393342.

Mickovski, S B and Thomson, C S. (in press). Developing a framework for the sustainability assessment of ecoengineering measures. Accepted for publication in Ecological Engineering.

Mickovski, S B and Thomson, C S. 2016. Innovative Approach in the Stabilisation of Coastal Slopes. Engineering Sustainability, doi: 10.1680/jensu.16.00047.

Mickovski, S.B., Gonzalez-Ollauri, A., Tardio, G. 2017. Novel approaches to quantification of the vegetation effects on soil strength. In: Proc 19th International Conference on Soil Mechanics and Geotechnical Engineering. W. Lee, J-S. Lee, H-K. Kim, D-S Kim (Eds). Seoul, Korea, September 17 - 22, 2017, pp 31673170 .

Muvuna J., Boutaleb T., Mickovski S. B. and Baker K. J. 2017. Systems engineering approach to design and modelling of smart cities. In Proc. International Conference for Students on Applied Engineering (ICSAE), Newcastle upon Tyne, 2016, pp. 437-440.

Santos, O.F.Jr, de Souza C. Jr, Scudelari, A.C., Freitas Neto, O., Amaro, V., Mickovski, S.B. 2015. Stability Analysis of Sea Cliffs in the Coastal Zone of Baía Formosa / Rio Grande do Norte State - Brazil. In: Proc. XV Panamerican Conference on Soil Mechanics and Geotechnical Engineering, Buenos Aires, Argentina, November 15-18, 2015, pp 1365-1368.

Schiechtl, H.M. and Stern, R. 1996. Ground bioengineering techniques for slope protection and erosion control. Blackwell Science, Oxford, UK, 146pp.

Tardio, G., González-Ollauri A and Mickovski S.B. 2016. A non-invasive preferential root distribution analysis methodology from a slope stability approach. Ecological Engineering 97: 46-57.

Tawelian, L.R. and Mickovski, S.B. 2016. The Implementation of Geotechnical Data Into the BIM Process. Procedia Engineering 143 (2016): 734-741.

van Staveren, M. Th. 2007. Extending to geotechnical risk management. In: Proc. $1^{\text {st }}$ Int'l Symposium on Geotechnical Safety and Risk, Oct. 18-19, 2007, Shanghai Tongji University, China. Pp1-12. 